\title{
How Pervasive is Eating Out in India?
}

\author{
Raghav Gaiha, \\ Faculty of Management Studies, \\ University of Delhi, \\ Raghbendra Jha, \\ Arndt-Corden Division of Economics \\ Research School of Pacific and Asian Studies \\ Australian National University, \\ \& \\ Vani S. Kulkarni, \\ Centre of South Asian Studies, \\ Yale University.
}

November 2009 


\title{
How Pervasive is Eating Out in India?
}

\begin{abstract}
A key feature of the economic transformation has been the change in the nature of the Indian diet. As global markets integrate and communication becomes better, diet transitions are unavoidable. There is a move away from inferior to superior foods and a substitution of traditional staples by primary food products that are more prevalent in western diets. These shifts are reflected in higher consumption of proteins, sugars, fats and vegetables. As part of this dietary transition, our analysis focuses on the pervasiveness of eating out. The analysis, based on a rich household survey for 2005, conducted jointly by University of Maryland and National Council of Applied Economic Research, broadly confirms the important role of urbanisation, demographic changes, expansion of middle class and its growing affluence in eating out, or, more generally, consumption of snacks, precooked meals and beverages. To the extent that even more deprived sections-not just in metros but also in rural areasare not immune to these evolving dietary patterns, and, given their limited access to medical care and dietary awareness, the health outcomes may well be grim.
\end{abstract}

Key words: Urbanisation, affluence, diets, eating out, health, mortality.

JEL Classification Codes: D12, N35, P46, Q18, 


\section{How Pervasive is Eating Out in India? ${ }^{1}$}

\section{Dietary Transition}

India is undergoing a rapid economic and demographic transformation. Since 1980 average living standards have experienced a sustained and rapid rise. The gross domestic product per capita rose by 230 per cent - a trend rate of 4 per cent annually. Poverty declined at an annual rate of 0.88 per cent during 1983-94 and at a slightly lower rate of 0.77 per cent during 1993-05. Life expectancy has risen from 54 years to 69 years while the (crude) birth rate has fallen from 34 to 22 over the period 1980-2008. Rapid economic growth has been accompanied by rising urbanisation. Between 1980-2000, the share of the urban population rose from 23 per cent to 28 per cent. By 2030, it is likely to be as high as 41 per cent.

The growth momentum was accelerated by wide ranging domestic and external liberalisation of the Indian economy in the 1990s. A key feature of the economic transformation has been the change in the nature of the Indian diet. As the global markets integrate and communication becomes better, diet transitions are unavoidable. There is a move away from inferior to superior foods and a substitution of traditional staples by primary food products that are more prevalent in western diets. These shifts are reflected in higher consumption of proteins, sugars, fats and vegetables.

Some of the underlying factors include expansion of the middle class, higher female participation, emergence of nuclear two-income families, a sharp age-divide in food preferences, with younger age-groups more susceptible to new foods advertised in the media, and a rapid growth of super markets and fast-food outlets.

Some dietary changes observed since the 1980s (based on FAOSTAT ${ }^{2}$ ) are delineated below:

- During the 1980 s, consumption of both animal and vegetable products rose sharply.

- Among animal products, the largest proportional increase was in the consumption of milk.

- Among vegetable products, there were large increases in rice, pulses, wheat, spices and oils.

\footnotetext{
${ }^{1}$ The computations were carried out competently by Raj Bhatia. We are grateful to Sonal Desai for clarifying a number of issues relating to the sample design and variables used in the household survey carried out jointly by University of Maryland and National Council of Applied Economic Research; and Ajay Mahal and A. V. Subramanian for sharing their research. We are especially grateful to Lawrence Haddad for his constructive advice in the initial stage, and Anil Deolalikar for his valuable help in econometric estimation. A. Venkatraman offered useful advice on the epidemiological transition in India. This study was funded by the British Government, under the Foresight Global Food and Farming Futures Project. The views expressed are, however, the sole responsibility of the authors.

${ }^{2}$ For details, see Pingali and Khwaja (2004), and Pingali (2007). For a more recent analysis, based on several rounds of the NSS household surveys, pointing to a downward shift of the calorie Engle consumption curve, see Deaton and Dreze (2009). Their conjecture that a major explanatory factor is improvement in social epidemiology of disease, easier access to drinking water, and transportation facilities is subject to rigorous validation. A related study focusing on nutrition-poverty link is Mahal and Karan (2008). For an alternative view emphasizing nutrition-poverty traps, see Jha et al. (2009).
} 
During the 1990s, the pattern of food consumption changed significantly.

- There was a marked increase in the consumption of animal products especially animal fats - but a relatively modest increase in that of vegetable products.

- Among the latter, there were large increases in the consumption of wheat, starchy roots, vegetable oils, sugar and sweeteners, and fruits while that of rice, pulses and other cereals declined.

- Among the starchy roots, potato recorded a sharp increase given its salience in energy-dense food products (e.g. fries and potato chips).

- Use of wheat has changed too, as there is a move away from the traditional chapatti to more commercialised and westernised bread products.

The health implications of the dietary transition are not clear-cut. A more varied and nutritionally balanced diet and higher levels of food hygiene are associated with better health. But there is a trade-off as more energy-dense foods are linked to a higher incidence of diet-related non-communicable diseases or NCDs (e.g. diabetes, coronary heart disease and certain types of cancer). ${ }^{3}$ Although India lags behind other developing countries in the epidemiological transition - decline in infectious disease mortality compensated for increasingly by higher mortality from chronic degenerative NCDs - there is some evidence of this transition taking place. ${ }^{4}$ The estimated deaths from NCDs are projected to rise from 3.78 million in 1990 (40.46 per cent of all deaths) to 7.63 million in 2020 (66.70 per cent of all deaths). ${ }^{5}$ Worse, many of these deaths occur at relatively early ages. About a quarter of the deaths occurred in the 35 to 64 age-group in urban areas.

\section{Data}

From this perspective, we report our findings on eating out, based on an analysis of a nationwide household survey, India Human Development Survey 2005 (IHDS), conducted jointly by University of Maryland and National Council of Applied Economic Research (NCAER).

IHDS covers over 41000 households residing in rural and urban areas, selected from 33 states. $^{6}$ The sample comprises 384 districts out of a total of 593 identified in 2001 census. Villages and urban blocks constituted the primary sampling unit from which households were selected.

The rural sample contains about half the households that were interviewed initially by NCAER in 1993-94 in a survey entitled Human Development Profile of India-HDPIand the other half of the sample households was drawn from both districts surveyed in HDPI as well as from districts located in the states and union territories not covered in HDPI. The original HDIP was a random sample of 33,230 households, located in 16 major states, 195 districts and 1765 villages. In states where the 1993-94 survey was

\footnotetext{
${ }^{3}$ For an admirably lucid exposition of growth of supermarkets and fast food outlets, and shifts in dietary patterns, see Timmer (2009).

${ }^{4}$ For an important contribution, see Popkin et al. (2001).

${ }^{5}$ Cited in Reddy et al. (2005).For a more recent assessment, see Mahal et al. (2009).

${ }^{6}$ This is a summary of the material provided by Sonal Desai.
} 
conducted and recontact details were available, 13593 households were randomly selected for reinterview in 2005. About 82 per cent of the households were contactable for reinterview resulting in a resurvey of 11,153 original households as well as 2,440 households which had separated from the original households but were still living in the same village.

In each district where reinterviews were conducted, two fresh villages were randomly selected using a probability proportional to size technique. In each village, 20 randomly selected households were selected.

Additionally, 3,993 households were randomly selected from the states where the 1993-94 survey was not conducted, or where recontact information was not available.

In order to draw a random sample of urban households, all urban areas in a state were listed in the order of their size with number of blocks drawn from each urban area allocated based on probability proportional to size. After determining the number of blocks, the enumeration blocks were selected randomly. From these enumeration blocks (of about 150-200 households), a complete household listing was obtained and a sample of 15 households was selected per block.

Comparison of IHDS data with the National Sample Survey or NSS (2004-05), National Family Health Survey III (2005-06) and Census (2001) confirms the robustness of IHDS data. For example, IHDS sample distribution on urban residence, caste and religion is remarkably similar to NSS and NFHS-III, although all three surveys (IHDS, NSS and NFHS) have higher proportions of households claiming Scheduled Caste status than enumerated in Census (2001).

\section{Cross-Tabulations}

Our focus is on the socio-economic status of households eating out, and their spatial distribution. The latter disaggregates household locations into rural and urban areas, and urban slums. A further disaggregation separates 6 metros from the rest. Eating out refers to meals or snacks served in restaurants, roadside eating places, tea and snack shops, and food vendors. Three sets of cross-tabulations are given below: the first focuses on location (rural, urban, urban slums, metros); the second on socio-economic characteristics of those eating out; and the third on amounts spent.

\section{(a) Location}

Tables 1 and 2 give the distribution of households eating out by location. In these and subsequent tables, two different types of locational classification are used: the first distinguishes metros, non-metro urban and (non-metro) rural areas; and the second distinguishes rural, urban and urban slums. As illustrated below, eating out is not just a feature of metros or urban areas but also of urban slums and rural areas. Admittedly, although it is less pervasive in urban slums and rural areas, it is non-negligible. Nor is eating out a feature of affluent households only, as it is not uncommon among the poor and other deprived sections. 
Table 1

Distribution of Households Eating Out by Location ${ }^{7}$

\begin{tabular}{|l|c|c|c|}
\hline Location & No & \multicolumn{3}{|c|}{$\begin{array}{c}\text { Whether Ate Out? } \\
\text { Yes } \\
\text { (percentage) }\end{array}$} \\
\hline Non-metro Rural & 74.67 & 25.33 & Total \\
\hline Metro & $(65.40)$ & $(56.67)$ & 100 \\
& 65.54 & 34.46 & $(62.94)$ \\
\hline Non-Metro Urban & $(9.08)$ & $(12.19)$ & 100 \\
& 67.67 & 32.33 & $(9.95)$ \\
\hline \multirow{2}{*}{ Total } & $(25.52)$ & $(31.14)$ & $(27.10)$ \\
\hline & 71.86 & 28.14 & 100 \\
& $(100)$ & $(100)$ & $(100)$ \\
\hline
\end{tabular}

The proportion of households eating out is well above one quarter. The highest proportion is found in the six metros, followed by non-metro urban, and rural area. ${ }^{8}$ The differences, however, are small. The differences among the metros are large, with over three-fourths of the households in Bangalore eating out, followed by Chennai, and then Mumbai. At the other extreme are Kolkatta (20.13 per cent) and Delhi (about 25 per cent). Another locational classification further corroborates the pervasiveness of eating out. Somewhat surprisingly, the proportion of households eating out was highest in urban slums (45.9 per cent), followed by urban areas (35.2 per cent) and then rural areas (27.29 per cent).

Table 2

Distribution of Households Eating Out in Metros

\begin{tabular}{|c|c|c|c|}
\hline Metro & No & $\begin{array}{c}\text { hether Ate } \\
\text { Yes } \\
\text { (Percenta }\end{array}$ & Total \\
\hline Mumbai & $\begin{array}{c}61.88 \\
(18.31)\end{array}$ & $\begin{array}{c}38.12 \\
(22.55)\end{array}$ & $\begin{array}{l}100 \\
(19.73)\end{array}$ \\
\hline Delhi & $\begin{array}{c}75.11 \\
(21.06)\end{array}$ & $\begin{array}{c}24.89 \\
(13.95)\end{array}$ & $\begin{array}{l}100 \\
(18.68)\end{array}$ \\
\hline Kolkata & $\begin{array}{c}79.87 \\
(38.04)\end{array}$ & $\begin{array}{c}20.13 \\
(19.16)\end{array}$ & $\begin{array}{l}100 \\
(31.74)\end{array}$ \\
\hline Chennai & $\begin{array}{c}47.84 \\
(8.17)\end{array}$ & $\begin{array}{c}52.16 \\
(17.81)\end{array}$ & $\begin{array}{l}100 \\
(11.39)\end{array}$ \\
\hline Bangalore & $\begin{array}{c}24.17 \\
(1.90)\end{array}$ & $\begin{array}{c}75.83 \\
(11.93)\end{array}$ & $\begin{array}{l}100 \\
\quad(5.25)\end{array}$ \\
\hline Hyderabad & $\begin{array}{c}63.18 \\
(12.52)\end{array}$ & $\begin{array}{c}36.82 \\
(14.59)\end{array}$ & $\begin{array}{l}100 \\
(13.21)\end{array}$ \\
\hline Total & $\begin{array}{l}66.66 \\
(100)\end{array}$ & $\begin{array}{l}33.34 \\
(100)\end{array}$ & $\begin{array}{c}100 \\
(100)\end{array}$ \\
\hline
\end{tabular}

\footnotetext{
${ }^{7}$ Figures in parenthesis indicate percentage of total respondents in that category. Thus, $65.40 \%$ of all households that did not eat out lived in non-metro rural areas.

${ }^{8}$ The six metros are Bangalore, Kolkatta, Chennai, Delhi, Mumbai and Hyderabad.
} 
As economic deprivation is highest among the STs, followed by the SCs and then OBCs, the cross-classification of households affiliated to these groups by whether they ate out is revealing. ${ }^{9}$ The proportion eating out was highest among the STs, followed by the OBCs and then Others. So the convenience and cheapness of eating out are presumably inducing relatively deprived households and/or those living in deprived areas to turn to this option in large numbers. As may be noted from subsequent cross-tabulations of eating out by poverty status, we find some striking differences ${ }^{10}$. In the metros, the proportion of non-poor eating out is more than five times higher than that of poor (36.73 per cent and 7.38 per cent, respectively). So clearly the relatively affluent display a stronger propensity to eat out. However, while it is not surprising that the proportion of non-poor eating out in non-metros is markedly lower (31.30 per cent), that of poor is higher (13.84 per cent). As we are unable to probe the quality and price differences, these may be key to the narrower gap between proportions of non-poor and poor eating out in non-metros.

Table 3

Distribution of Households Eating Out by Caste

\begin{tabular}{|l|c|c|c|}
\hline \multicolumn{1}{|c|}{ Caste } & \multicolumn{3}{|c|}{$\begin{array}{c}\text { Whether Ate Out? } \\
\text { Yes } \\
\text { (percentage) }\end{array}$} \\
\hline Scheduled Caste (SC) & $\begin{array}{c}75.57 \\
(22.14)\end{array}$ & $\begin{array}{c}24.43 \\
(17.0)\end{array}$ & $\begin{array}{c}100 \\
(20.61)\end{array}$ \\
\hline Scheduled Tribe & 71.46 & 28.54 & 100 \\
(ST) & $(7.39)$ & $(7.0)$ & $(7.28)$ \\
\hline Other Backward & 68.22 & 31.78 & 100 \\
Castes (OBC) & $(34.97)$ & $(38.61)$ & $(36.06)$ \\
\hline Others & 69.26 & 30.74 & 100 \\
& $(35.50)$ & $(37.39)$ & $(36.05)$ \\
\hline Total & 70.35 & 29.65 & 100 \\
& $(100)$ & $(100)$ & $(100)$ \\
\hline
\end{tabular}

Whether the decision to eat out is linked to the family type - nuclear or joint - is sought to be captured in the cross-tabulation in Table 4. ${ }^{11}$ About 28 per cent of nuclear families ate out as compared with a slightly higher share of joint families. The corresponding proportion of the residual group was considerably lower (over 19 per cent). Among those who ate out, more than 50 per cent belonged to nuclear families and a little under half to joint families. If joint families displayed a stronger propensity to eat out, it could be in part a manifestation of diverse living arrangements (e.g. some relatives may simply live under the same roof but may not share meals).

\footnotetext{
${ }^{9}$ For details, see Gaiha et al. (2008).

${ }^{10}$ The poverty line used is the official poverty line in terms of monthly per capita expenditure. For details, see Himanshu (2007).

${ }^{11}$ A nuclear family is one that includes a married couple, with or without both spouses living together, and their children, if any. A joint family includes other relatives. Other cases (e.g. a widow/widower or a separated spouse living alone) are combined in the residual group.
} 
Table 4

Distribution of Households Eating Out by Family Type

\begin{tabular}{|l|c|c|c|}
\hline Family Type & \multicolumn{3}{|c|}{$\begin{array}{c}\text { Whether Ate Out? } \\
\text { Yes } \\
\text { (percentage) }\end{array}$} \\
\hline Nuclear & No Total \\
\hline Joint & 72.16 & $\begin{array}{c}27.84 \\
(52.43)\end{array}$ & $\begin{array}{c}100 \\
(52.86)\end{array}$ \\
\hline \multirow{2}{*}{ Other } & $(53.03)$ & 30.12 & 100 \\
& $(38.88$ & $(42.16)$ & $(39.29)$ \\
\hline \multirow{2}{*}{ Total } & 80.63 & 19.37 & 100 \\
& $(8.81)$ & $(5.42)$ & $(7.86)$ \\
\hline & 71.93 & 28.07 & 100 \\
& $(100)$ & $(100)$ & \\
\hline
\end{tabular}

Let us now turn to cross-tabulations of expenditure on eating out and socio-economic status of households.

In Table 5, a cross-tabulation of eating out (monthly) expenditure by monthly (household) per capita expenditure is given. Note that the poverty cut-off point for the major states lie in the monthly per capita expenditure range - Rs 300-500. So those in the lower range may be described as acutely or extremely poor while those in the range $>$ Rs 1000 as relatively affluent. To contrast these results with those from the sample of households living in the metros, a cross-tabulation for the latter is given in Table 6.

Table 5

Distribution of Household Expenditure on Eating Out by monthly per capita expenditure (MPCE)(Rs)

\begin{tabular}{|l|c|c|c|c|c|}
\hline $\begin{array}{l}\text { Eating Out } \\
\text { (Rs) }\end{array}$ & $<300$ & $300-500$ & $500-1000$ & $>1000$ & Total \\
\hline None & $\begin{array}{c}12.82 \\
(87.52)\end{array}$ & $\begin{array}{c}28.71 \\
(79.19)\end{array}$ & $\begin{array}{c}38.40 \\
(68.20)\end{array}$ & $\begin{array}{c}20.07 \\
(57.44)\end{array}$ & $\begin{array}{c}100 \\
(70.35)\end{array}$ \\
\hline $1-99$ & $\begin{array}{c}8.57 \\
(10.37)\end{array}$ & $\begin{array}{c}27.55 \\
(13.47)\end{array}$ & $\begin{array}{c}44.84 \\
(14.12)\end{array}$ & $\begin{array}{c}19.03 \\
(9.66)\end{array}$ & $\begin{array}{c}100 \\
(12.47)\end{array}$ \\
\hline $100-199$ & $\begin{array}{c}2.24 \\
(1.85)\end{array}$ & $\begin{array}{c}16.87 \\
(5.61)\end{array}$ & $\begin{array}{c}49.04 \\
(10.50)\end{array}$ & $\begin{array}{c}31.85 \\
(10.99)\end{array}$ & $\begin{array}{c}100 \\
(8.48)\end{array}$ \\
\hline $200-499$ & $\begin{array}{c}0.39 \\
(0.25)\end{array}$ & $\begin{array}{c}6.18 \\
(1.59)\end{array}$ & $\begin{array}{c}37.71 \\
(6.25)\end{array}$ & $\begin{array}{c}55.72 \\
(14.89)\end{array}$ & $\begin{array}{c}100 \\
(6.57)\end{array}$ \\
\hline$>500$ & 0.10 & $\begin{array}{c}1.69 \\
(0.14)\end{array}$ & $\begin{array}{c}17.14 \\
(0.92)\end{array}$ & $\begin{array}{c}81.08 \\
(7.03)\end{array}$ & $\begin{array}{c}100 \\
(2.13)\end{array}$ \\
\hline Total & 10.30 & 25.51 & 39.61 & $\begin{array}{c}24.58 \\
(100)\end{array}$ & $\begin{array}{c}100 \\
(100)\end{array}$ \\
\hline
\end{tabular}


One striking feature is that the proportion of households eating out rises among the three lowest expenditure ranges and then falls sharply in the highest range ( $>$ Rs 1000). Another striking result is that amounts spent vary in a somewhat complex fashion. If we consider those in extreme or moderate poverty (i.e. the first two monthly expenditure ranges), small or moderately high fractions of households spending small amounts on eating out fall sharply. In the intermediate range of monthly expenditure (Rs 500-1000), the proportions spending small to moderate amounts is higher and a non-negligible proportion spends more than moderate amounts on eating out. In the highest expenditure range or among the relatively affluent (i.e. with a monthly per capita expenditure $>$ Rs 1000), there is a clear progression of proportions spending larger amounts on eating out except in the highest range of eating out expenditure ( $>$ Rs 500). But even in this cell, the share of the relatively affluent is non-negligible (about 7 per cent). So the upshot is that relatively affluent are more likely to eat out, as also to spend larger amounts.

Table 6

Distribution of Household Expenditure on Eating Out by monthly per capita expenditure (MPCE)(Rs) in Metros

\begin{tabular}{|c|c|c|c|c|c|}
\hline $\begin{array}{l}\text { Eating Out } \\
\text { (Rs) }\end{array}$ & $<300$ & $300-500$ & 500-1000 & $>1000$ & Total \\
\hline None & $\begin{array}{c}3.91 \\
(95.12)\end{array}$ & $\begin{array}{c}17.93 \\
(86.24)\end{array}$ & $\begin{array}{c}43.62 \\
(71.75)\end{array}$ & $\begin{array}{c}34.54 \\
(53.70)\end{array}$ & $\begin{array}{l}100 \\
(66.66)\end{array}$ \\
\hline $1-99$ & $\begin{array}{c}1.65 \\
(4.18)\end{array}$ & $\begin{array}{c}13.35 \\
(6.66)\end{array}$ & $\begin{array}{l}45.47 \\
(7.76)\end{array}$ & $\begin{array}{c}39.53 \\
(6.38)\end{array}$ & $\begin{array}{l}100 \\
(6.91)\end{array}$ \\
\hline 100-199 & $\begin{array}{c}0.18 \\
(0.71)\end{array}$ & $\begin{array}{c}6.64 \\
(5.09)\end{array}$ & $\begin{array}{c}51.55 \\
(13.51)\end{array}$ & $\begin{array}{l}41.63 \\
! 0.31)\end{array}$ & $\begin{array}{l}100 \\
(10.62)\end{array}$ \\
\hline 200-499 & $\begin{array}{c}0.0 \\
(0.0)\end{array}$ & $\begin{array}{c}2.66 \\
(2.01)\end{array}$ & $\begin{array}{c}24.58 \\
(6.37)\end{array}$ & $\begin{array}{c}72.77 \\
(17.81)\end{array}$ & $\begin{array}{l}100 \\
(10.50)\end{array}$ \\
\hline$>500$ & $\begin{array}{c}0.0 \\
(0.0)\end{array}$ & $\begin{array}{c}0.0 \\
(0.0)\end{array}$ & $\begin{array}{c}4.72 \\
(0.62)\end{array}$ & $\begin{array}{c}95.28 \\
(11.79)\end{array}$ & $\begin{array}{l}100 \\
\quad(5.31)\end{array}$ \\
\hline Total & $\begin{array}{l}2.74 \\
(100)\end{array}$ & $\begin{array}{l}13.86 \\
(100)\end{array}$ & $\begin{array}{l}40.53 \\
(100)\end{array}$ & $\begin{array}{l}42.87 \\
(100)\end{array}$ & $\begin{array}{c}100 \\
(100)\end{array}$ \\
\hline
\end{tabular}

This comes out more sharply in the sub-sample for the metros in Table 6. Among the relatively affluent, for example, the proportion spending larger amounts on eating out rises from over 6 per cent to about 18 per cent but falls to about 12 per cent in the highest eating out expenditure range (i.e. $>$ Rs 500).

To avoid cluttering the text, and to throw more light on the differences between the poor and non-poor, let us first consider the sub-sample for the metros in Table 7. While the proportion spending larger amounts on eating out decreases sharply among the poor, there is a progression among the non-poor except in the highest range of eating out expenditure. In the non-metro sub-sample, however, while the proportion of poor spending larger amounts drops sharply, it also falls among the non-poor but more slowly. 
As monthly per capita expenditure is only a proxy for the standard of living, it is worthwhile to examine linkages between eating out and castes - some of which are highly poverty prone. Two cross-tabulations are given below: one for the sub-sample for the metros and another for the non-metros. Two remarks are in order.

Table 7

Distribution of Household Expenditure on Eating Out by Poverty Status in Metros

\begin{tabular}{|l|c|c|c|}
\hline Eating Out (Rs) & Non-Poor & Poor & Total \\
\hline \multirow{2}{*}{ None } & 83.96 & 16.04 & 100 \\
& $(63.27)$ & $(92.62)$ & $(66.66)$ \\
\hline \multirow{2}{*}{$1-99$} & 92.22 & 7.78 & 100 \\
& $(7.21)$ & $(4.66)$ & $(6.91)$ \\
\hline \multirow{2}{*}{ 100-199 } & 98.27 & 1.73 & 100 \\
& $(11.80)$ & $(1.59)$ & $(10.62)$ \\
\hline \multirow{2}{*}{ 200-499 } & 99.08 & 0.92 & 100 \\
& $(11.76)$ & $(0.84)$ & $(10.50)$ \\
\hline \multirow{2}{*}{$>500$} & 99.36 & 0.64 & 100 \\
& $(5.96)$ & $(0.29)$ & $(5.31)$ \\
\hline \multirow{2}{*}{ Total } & 88.46 & 11.54 & 100 \\
& $(100)$ & $(100)$ & $(100)$ \\
\hline
\end{tabular}

Table 8

Distribution of Household Expenditure on Eating Out by Poverty Status in Non-Metros

\begin{tabular}{|l|c|c|c|}
\hline Eating Out (Rs) & Non-Poor & Poor & Total \\
\hline \multirow{2}{*}{ None } & 73.66 & 26.34 & 100 \\
& $(68.70)$ & $(86.16)$ & $(72.57)$ \\
\hline \multirow{2}{*}{$1-99$} & 83.55 & 16.65 & 100 \\
& $(14.67)$ & $(10.29)$ & $(13.69)$ \\
\hline \multirow{2}{*}{$100-199$} & 91.56 & 8.44 & 100 \\
& $(8.71)$ & $(2.81)$ & $(7.40)$ \\
\hline \multirow{2}{*}{$200-499$} & 96.93 & 3.07 & 100 \\
& $(6.37)$ & $(0.71)$ & $(1.22)$ \\
\hline \multirow{2}{*}{$>500$} & 99.26 & 0.74 & 100 \\
& $(1.56)$ & $(0.04)$ & $(1.22)$ \\
\hline \multirow{2}{*}{ Total } & 77.81 & 22.19 & 100 \\
& $(100)$ & $(100)$ & $(100)$ \\
\hline
\end{tabular}

One is that proportions of those eating out are not higher in all cases in the metros. While those of the SCs and OBCs are higher in the metros - especially of the latter - that of the STs is much higher in the non-metros. The second remark is that the amounts spent by each of these deprived groups - with varying degrees of deprivation - are higher in the metros. So it follows that even relatively deprived groups are not immune to changing life styles and dietary changes. 
Table 9

Distribution of Household Expenditure on Eating Out by Caste in Metros

\begin{tabular}{|l|c|c|c|c|c|}
\hline $\begin{array}{l}\text { Eating Out } \\
\text { (Rs) }\end{array}$ & SC & ST & OBC & Others & Total \\
\hline None & $\begin{array}{c}26.59 \\
(73.21)\end{array}$ & $\begin{array}{c}1.64 \\
(82.09)\end{array}$ & $\begin{array}{c}25.14 \\
(60.79)\end{array}$ & $\begin{array}{c}46.63 \\
(66.29)\end{array}$ & $\begin{array}{c}100 \\
(66.29)\end{array}$ \\
\hline \multirow{2}{*}{$1-99$} & 25.95 & 0.28 & 32.10 & 41.67 & 100 \\
& $(7.41)$ & $(1.46)$ & $(8.05)$ & $(6.14)$ & $(6.91)$ \\
\hline \multirow{2}{*}{$100-199$} & 24.62 & 0.96 & 39.62 & 34.80 & 100 \\
& $(10.80)$ & $(7.66)$ & $(15.27)$ & $(7.88)$ & $(10.62)$ \\
\hline \multirow{2}{*}{$200-499$} & 16.20 & 0.47 & 31.20 & 52.13 & 100 \\
& $(7.02)$ & $(3.67)$ & $(11.88)$ & $(11.67)$ & $(10.50)$ \\
\hline$>500$ & 7.12 & 1.29 & 20.80 & 70.80 & 100 \\
& $(1.56)$ & $(5.13)$ & $(4.0)$ & $(8.01)$ & \\
\hline \multirow{2}{*}{ Total } & 24.21 & 1.33 & 27.56 & 46.89 & 100 \\
& $(100)$ & $(100)$ & $(100)$ & $(100)$ & $(100)$ \\
\hline
\end{tabular}

Table 10

Distribution of Household Expenditure on Eating Out by Caste in Non-Metros

\begin{tabular}{|l|c|c|c|c|c|}
\hline $\begin{array}{l}\text { Eating Out } \\
\text { (Rs) }\end{array}$ & SC & ST & OBC & Others & Total \\
\hline None & $\begin{array}{c}22.96 \\
(76.82)\end{array}$ & $\begin{array}{c}8.65 \\
(72.84)\end{array}$ & $\begin{array}{c}35.83 \\
(70.82)\end{array}$ & $\begin{array}{c}32.56 \\
(71.65)\end{array}$ & $\begin{array}{c}100 \\
(72.57)\end{array}$ \\
\hline \multirow{2}{*}{$1-99$} & 21.33 & 11.15 & 40.59 & 26.93 & 100 \\
& $(13.46)$ & $(17.72)$ & $(15.14)$ & $(11.18)$ & $(13.69)$ \\
\hline \multirow{2}{*}{$100-199$} & 17.07 & 6.94 & 40.41 & 35.58 & 100 \\
& $(5.82)$ & $(5.96)$ & $(8.15)$ & $(7.99)$ & $(7.40)$ \\
\hline \multirow{2}{*}{ 200-499 } & 14.05 & 4.33 & 34.90 & 46.72 & 100 \\
& $(3.31)$ & $(2.57)$ & $(4.86)$ & $(7.24)$ & $(5.11)$ \\
\hline \multirow{2}{*}{ (500 } & 10.26 & 6.41 & 31.00 & 52.33 & 100 \\
& $(0.58)$ & $(0.91)$ & $(1.03)$ & $(1.94)$ & $(1.22)$ \\
\hline \multirow{2}{*}{ Total } & 21.69 & 8.62 & 36.71 & 32.98 & 100 \\
& $(100)$ & $(100)$ & $(100)$ & $(100)$ & $(100)$ \\
\hline
\end{tabular}

Table 11 throws light on eating out amounts in three different locations: rural, urban and urban slums. The contrast in some respects is striking. The proportions of households spending larger amounts decreases in rural areas but not so sharply; in the urban areas, by contrast, the proportion of households spending larger amounts rises but slowly until the highest eating out expenditure range. In fact, about 16 per cent of the households spend moderately high or high amounts on eating out. But the urban slums are not far behind. About 33 per cent of the households spent small or slightly larger amounts but about 14 per cent also spent moderately high or high amounts. As noted already, thus even deprived locations are not immune to life-style changes and convenience of eating out. 
Table 11

Distribution of Household Expenditure on Eating Out by Location

\begin{tabular}{|l|c|c|c|c|}
\hline Eating Out (Rs) & Rural & Urban & Urban Slums & Total \\
\hline None & $\begin{array}{c}74.82 \\
(72.71)\end{array}$ & $\begin{array}{c}23.88 \\
(64.80)\end{array}$ & $\begin{array}{c}1.29 \\
(54.10)\end{array}$ & $\begin{array}{c}100 \\
(70.35)\end{array}$ \\
\hline \multirow{2}{*}{$1-99$} & 77.45 & 20.06 & 2.50 & 100 \\
& $(13.34)$ & $(9.65)$ & $(18.50)$ & $(12.47)$ \\
\hline \multirow{2}{*}{$100-199$} & 67.45 & 29.68 & 2.86 & 100 \\
& $(7.90)$ & $(9.71)$ & $(14.44)$ & $(8.480$ \\
\hline \multirow{2}{*}{$200-499$} & 54.54 & 42.45 & 3.01 & 100 \\
& $(4.95)$ & $(10.75)$ & $(11.76)$ & $(6.57)$ \\
\hline$>500$ & 37.20 & 61.86 & 0.95 & 100 \\
& $(1.10)$ & $(5.09)$ & $(1.20)$ & $(2.13)$ \\
\hline \multirow{2}{*}{ Total } & 72.39 & 25.93 & 1.68 & 100 \\
& $(100)$ & $(100)$ & $(100)$ & $(100)$ \\
\hline
\end{tabular}

In Tables 12, 13 and 14, we give cross-classifications of household expenditure on eating out by type of family in the aggregate sample, metros and rural areas (excluding the metros), respectively. Let us first consider the results from the aggregate sample.

Among those who eat out in nuclear families, there is a steady decrease in the share of households as expenditure on eating out rises. In fact, a large majority of these (76 per cent) spent small amounts (i.e. $<$ Rs 200) while the remaining spent $>$ Rs 200 .

The pattern is similar among joint families. About 71 per cent spent small amounts $(<$ Rs 200), and the remaining moderate amounts ( $>$ Rs200).

If these results are compared with those for the metros, the patterns are different, as shown in Table 13. It is not just that more nuclear families eat out, they also tend to spend larger amounts (relative to the aggregate sample). About 50 per cent of these spent small amounts $(<$ Rs 200) while about 17 per cent spent large amounts $(>$ Rs 500 ). Among the joint families, a considerably higher proportion ate out. However, about half spent small amounts $(<$ Rs 200) while over 16 per cent spent large amounts (>Rs 500). So more joint families in the metros ate out and spent larger amounts too, as compared with the aggregate sample. 
Table 12

Distribution of Expenditure on Eating Out by Family Type

(Aggregate)

\begin{tabular}{|l|c|c|c|c|}
\hline Eating Out (Rs) & Nuclear & Joint & Other & Total \\
\hline None & $\begin{array}{c}53.03 \\
(72,16)\end{array}$ & $\begin{array}{c}38.17 \\
(69.88)\end{array}$ & $\begin{array}{c}8.81 \\
(80.63)\end{array}$ & $\begin{array}{c}100 \\
(71.93)\end{array}$ \\
\hline \multirow{2}{*}{-99 } & $\begin{array}{c}55.79 \\
(13.67)\end{array}$ & $\begin{array}{c}38.15 \\
(12.58)\end{array}$ & $\begin{array}{c}6.07 \\
(10.01)\end{array}$ & $\begin{array}{c}100 \\
(12.95)\end{array}$ \\
\hline $100-199$ & $\begin{array}{c}50.59 \\
(7.42)\end{array}$ & $\begin{array}{c}44.04 \\
(8.69)\end{array}$ & $\begin{array}{c}5.36 \\
(5.29)\end{array}$ & $\begin{array}{c}100 \\
(7.75)\end{array}$ \\
\hline $200-499$ & $\begin{array}{c}48.08 \\
(5.18)\end{array}$ & $\begin{array}{c}47.57 \\
(6.90)\end{array}$ & $\begin{array}{c}4.35 \\
(3.16)\end{array}$ & $\begin{array}{c}100 \\
(5.70)\end{array}$ \\
\hline$>500$ & 49.70 & 46.01 & $\begin{array}{c}4.29 \\
(0.91)\end{array}$ & $\begin{array}{c}100 \\
(1.67)\end{array}$ \\
\hline Total & $(1.57)$ & $(1.95)$ & $\begin{array}{c}7.86 \\
(100)\end{array}$ & $\begin{array}{c}100 \\
(100)\end{array}$ \\
\hline
\end{tabular}

Table 13

Distribution of Expenditure on Eating Out by Family Type in Metros

\begin{tabular}{|l|c|c|c|c|}
\hline Eating Out (Rs) & Nuclear & Joint & Other & Total \\
\hline \multirow{2}{*}{ None } & $\begin{array}{l}63.77 \\
(69.10)\end{array}$ & $\begin{array}{c}28.73 \\
(60.10)\end{array}$ & $\begin{array}{c}7.49 \\
(75.63)\end{array}$ & $\begin{array}{c}100 \\
(66.66)\end{array}$ \\
\hline \multirow{2}{*}{$1-99$} & 57.47 & 35.96 & 6.56 & 100 \\
& $(6.46)$ & $(7.80)$ & $(6.87)$ & $(6.91-$ \\
\hline \multirow{2}{*}{$100-199$} & 53.94 & 40.30 & 5.76 & 100 \\
& $(9.0)$ & $(13.43)$ & $(9.26)$ & $(10.62)$ \\
\hline \multirow{2}{*}{ 200-499 } & 59.95 & 36.76 & 3.29 & 100 \\
& $(10.23)$ & $(12.11)$ & $(5.24)$ & $(10.50)$ \\
\hline \multirow{2}{*}{ 500 } & 56.84 & 39.43 & 3.73 & 100 \\
& $(4.90)$ & $(6.57)$ & $(3.0)$ & $(100)$ \\
\hline \multirow{2}{*}{ Total } & 61.52 & 31.87 & 6.60 & 100 \\
& $(100)$ & $(100)$ & $(100)$ & $(100)$ \\
\hline
\end{tabular}

In the rural areas, about the same proportion of nuclear and joint families (about 25 per cent) ate out and large majorities ( 84 per cent and 78 per cent, respectively) spent small amounts, while a larger segment of the latter spent amounts exceeding Rs 200.

Some of the key results of the cross-tabulations are illustrated graphically using pie charts in the Annex. 
Table 14

Distribution of Expenditure on Eating Out by Family Type in Rural Areas

(Excluding Metros)

\begin{tabular}{|l|c|c|c|c|}
\hline Eating Out (Rs) & Nuclear & Joint & Other & Total \\
\hline \multirow{2}{*}{ None } & 50.55 & 40.58 & 8.87 & 100 \\
& $(74.71)$ & $(7.53)$ & $(83.21)$ & $(74.48)$ \\
\hline \multirow{2}{*}{$1-99$} & 54.62 & 39.84 & 5.54 & 100 \\
& $(15.40)$ & $(13.58)$ & $(9.91)$ & $(14.21)$ \\
\hline \multirow{2}{*}{$100-199$} & 46.65 & 48.32 & 5.03 & 100 \\
& $(6.12)$ & $(7.66)$ & $(4.19)$ & $(6.61)$ \\
\hline \multirow{2}{*}{ 200-499 } & 40.09 & 55.24 & 4.67 & 100 \\
& $(3.12)$ & $(5.19)$ & $(2.30)$ & $(3.92)$ \\
\hline \multirow{2}{*}{$>500$} & 41.51 & 54.56 & 3.93 & 100 \\
& $(0.65)$ & $(1.04)$ & $(0.39)$ & $(0.79)$ \\
\hline \multirow{2}{*}{ Total } & 50.39 & 41.67 & 7.94 & 100 \\
& $(100)$ & $(100)$ & $(100)$ & $(100)$ \\
\hline
\end{tabular}

In sum, eating out is a pervasive phenomenon - especially in the urban areas and, more specifically, in the metros. While relatively affluent are more prone to eating out and spend larger amounts, some of the deprived segments, using not just income/expenditure criteria but also caste and location, do not seem to lag far behind. Nor is eating out merely an urban phenomenon, as large segments in rural areas eat out too.

\section{Heckman Selection Model}

While these cross-tabulations yielded some insights into the pervasiveness of the eating out phenomenon, the marginal contributions of household traits - including their poverty status, demographic composition, whether a nuclear or a joint family and locational effects could not be assessed. To do so, we have experimented with the Heckman selection model. This comprises two stages: first, the decision to eat is analysed, followed by how amounts spent on eating out vary with household and other characteristics.

As detailed expositions of the Heckman model are available in various text books, we draw upon Wooldridge (2006).

The approach to incidental truncation is to add an explicit selection equation to the population model of interest:

$$
\begin{aligned}
& y=x \beta+u, E(u \mid x)=0 \\
& s=1[z \gamma+v \geq 0],
\end{aligned}
$$

where $\mathrm{s}=1$ if we observe $\mathrm{y}$, and 0 otherwise. As the elements of $\mathrm{x}$ and $\mathrm{z}$ are always observed, we write $\mathrm{x} \beta=\beta_{0}+\beta_{1} \mathrm{x}_{1}+\beta \mathrm{x}_{2}+\ldots \ldots \ldots . \beta_{\mathrm{k}} \mathrm{x}_{\mathrm{k}}$ and $\mathrm{z} \gamma$ $=\gamma_{0}+\gamma_{1} z_{1}+\ldots \ldots \ldots \ldots \ldots \gamma_{\mathrm{m}} z_{\mathrm{m}}$. 
The equation of primary interest is (1), and $\beta$ could be estimated by OLS given a random sample. The selection equation, (2), depends on observed variables, $\mathrm{z}_{\mathrm{h}}$, and an unobserved error, $v$. Exogeneity of $z$ implies $E(u \mid x, z)=0$. In fact, for the model that we propose to estimate, $x$ must be a subset of $z$.

The error term, $v$, in the sample selection equation is assumed to be independent of $z$ (and therefore $\mathrm{x}$ ). It is also assumed that $\mathrm{v}$ has a standard normal distribution. Any correlation between $u$ and $v$ causes a sample selection problem.

As $u$ and $v$ are related, and $v$ has a standard normal distribution, it is easy to show that $\mathrm{E}(v \mid \mathrm{z}, \mathrm{s})$ is simply the inverse Mills ratio, $\lambda(\mathrm{zy})$, when $\mathrm{s}=1{ }^{12}$ This leads to the important equation

$$
\mathrm{E}(\mathrm{y} \mid \mathrm{z}, \mathrm{s})=\mathrm{x} \beta+\rho \mathrm{E}(\mathrm{v} \mid \mathrm{z}, \mathrm{s})
$$

Equation (3) shows that expected value of y, given $z$ and observability of $y$, is equal to $\mathrm{x} \beta$, plus an additional term that depends on the inverse Mills ratio evaluated at $z \gamma$. This equation shows that we can estimate $\beta$ by using only the selected sample, provided we include $\gamma(\mathrm{z} \gamma)$ as an additional regressor.

If $\rho=0, \lambda$ (zy) does not appear, and OLS of $y$ on $x$ using the selected sample consistently estimates $\beta$. Otherwise, effectively the variable, $\lambda(z y)$, correlated with $\mathrm{x}$, is omitted. $\rho=0$ when $u$ and $v$ are uncorrelated.

Since $\lambda$ is unknown, we cannot evaluate $\lambda\left(z_{i} \gamma\right)$ for each $i$. However, given the assumptions, and, with $\mathrm{s}$ also given, $\mathrm{z}$ follows a probit model

$\mathrm{P}(\mathrm{s}=1 \mid \mathrm{z})=\Phi(\mathrm{z} \gamma)$

So $\gamma$ is estimated by probit of $s_{i}$ on $z_{i}$, using the entire sample. In a second step, $\beta$ is estimated from a regression of $y_{i}$ on $x_{i}, \hat{\lambda}_{i}$, using the selected sample for which $\mathrm{s}_{\mathrm{i}}=1$. The $\hat{\beta}_{\mathrm{j}}$ are consistent and approximately normally distributed. The $\mathrm{t}$ statistic on $\hat{\lambda}_{\mathrm{i}}$ tests $\mathrm{H}_{0}=0$. Under $\mathrm{H}_{0}$ there is no selection bias.

An alternative to this two-step estimation is full maximum likelihood estimation. This requires obtaining the joint distribution of y and s. Usually, the two-step procedure is applied first to test for selection bias. After the selection bias is confirmed, the regression and selection equation are estimated jointly by MLE (Wooldridge, 2006). ${ }^{13}$

\footnotetext{
${ }^{12}$ For details, see Wooldridge (2006).

${ }^{13}$ Adkins and Hill (2008) also recommend the MLE procedure. They observe "In most instances, it is preferable to estimate the full model, both the selection equation and the equation of interest, jointly by maximum likelihood" (p.399).
} 


\section{Results}

As the two-step procedure rejects the null, $\mathrm{H}_{0}=0$, shown in Table 15 , our comments are confined to the MLE results in Table 16.

Let us first consider the probit results. The main findings are:

- Both metro and non-metro urban locations induce eating out, relative to the rural. As life style changes in these locations have been more dramatic and convenience of eating out is greater, these are plausible results.

- Both nuclear and joint families display higher propensities to eat out relative to others. Between the two, joint families are more likely to eat out.

- While the coefficient of SCs/STs is negative, it is weakly significant, implying a lower propensity to eat out, relative to the omitted group of Others. That of OBCs is positive and significant, suggesting that they are more likely to eat out.

- The higher the number of adult males in paid work in the two age groups, 18 to 24 years, and 25 to 45 years, the greater is the likelihood of such households eating out. The same applies to the number of adult females in paid employment in these age groups.

- Controlling for the effects of these and other right side variables, the higher the ratio of per capita expenditure to the poverty cut-off expenditure, the higher is the probability of such households eating out. This confirms the important role of growing affluence in dietary changes.

- We have further examined whether the sources of income matter too. The higher the share of salary in household income, the greater is the likelihood of eating out. While the effect of higher share of business income is positive too, it is weakly significant.

- The higher the number of adult males in paid work in the two age groups, 18 to 24 years, and 25 to 45 years, the greater is the likelihood of such households eating out. The same applies to the number of adult females in paid employment in these age groups. 
Table 15

Heckman Selection Model - Two-Step Estimates

\begin{tabular}{|c|c|c|c|c|}
\hline \multirow{6}{*}{$\begin{array}{l}\text { Heckman selection model - two-step estimates } \\
\text { (regression model with sample selection) }\end{array}$} & \multicolumn{2}{|c|}{ Number of 0} & \multicolumn{2}{|l|}{41349} \\
\hline & \multicolumn{2}{|c|}{ Censored obs } & 29697 & \\
\hline & \multicolumn{2}{|c|}{ Uncensored obs } & 11652 & \\
\hline & \multicolumn{2}{|c|}{ Wald chi2(20) } & 1977.64 & \\
\hline & \multicolumn{2}{|c|}{ Prob > chi2 } & \multicolumn{2}{|l|}{0.0000} \\
\hline & Coef. & Std. Err. & $z$ & $P>Z$ \\
\hline \multicolumn{5}{|l|}{ Eating out - Rs. } \\
\hline Metro & 97.41035 & 9.153334 & 10.64 & 0 \\
\hline Urban & 17.13643 & 6.649995 & 2.58 & 0.01 \\
\hline $\mathrm{SC} / \mathrm{ST}$ & -38.28974 & 6.758803 & -5.67 & 0 \\
\hline OBC & -57.63362 & 6.22415 & -9.26 & 0 \\
\hline Expenditure Poverty Ratio & 17.29877 & 1.543485 & 11.21 & 0 \\
\hline No. of adult males in paid work age group $18-24$ & -6.422317 & 6.5436 & -0.98 & 0.326 \\
\hline No. of adult males in paid work age group $25-45$ & 6.749505 & 5.046546 & 1.34 & 0.181 \\
\hline No. of adult males in paid work age group $>45$ & 11.13983 & 6.466939 & 1.72 & 0.085 \\
\hline share of salary in total income & -0.4735356 & 0.3452486 & -1.37 & 0.17 \\
\hline share of business income in total income & 0.4673173 & 0.1222451 & 3.82 & 0 \\
\hline cons & 429.4722 & 36.46348 & 11.78 & 0 \\
\hline \multicolumn{5}{|l|}{ Recode Eating out (0/1) } \\
\hline Metro & 0.2081591 & 0.0230919 & 9.01 & 0 \\
\hline Urban & 0.1858965 & 0.0159761 & 11.64 & 0 \\
\hline Nuclear Family & 0.2740344 & 0.0282138 & 9.71 & 0 \\
\hline Joint family & 0.3677165 & 0.0288986 & 12.72 & 0 \\
\hline SC/ST & -0.0411038 & 0.0177504 & -2.32 & 0.021 \\
\hline OBC & 0.1123784 & 0.0159338 & 7.05 & 0 \\
\hline Expenditure Poverty Ratio & 0.0931872 & 0.0030568 & 30.49 & 0 \\
\hline No. of adult males in paid work age group $18-24$ & 0.0889712 & 0.0172724 & 5.15 & 0 \\
\hline No. of adult males in paid work age group $25-45$ & 0.0771043 & 0.0127216 & 6.06 & 0 \\
\hline No. of adult males in paid work age group $>45$ & -0.0081029 & 0.0179003 & -0.45 & 0.651 \\
\hline No. of adult females in paid work age group $18-24$ & 0.159953 & 0.0282207 & 5.67 & 0 \\
\hline No. of adult females in paid work age group $25-45$ & 0.1354875 & 0.0167471 & 8.09 & 0 \\
\hline No. of adult females in paid work age group >45 & -0.0170181 & 0.0284469 & -0.6 & 0.55 \\
\hline share of salary in total income & 0.1254854 & 0.0165585 & 7.58 & 0 \\
\hline share of business income in total income & 0.0012523 & 0.000547 & 2.29 & 0.022 \\
\hline cons & -1.303558 & 0.0310907 & -41.93 & 0 \\
\hline \multicolumn{5}{|l|}{ mills } \\
\hline lambda & -256.9678 & 24.87149 & -10.33 & 0 \\
\hline rho & -0.79844 & & & \\
\hline sigma & 321.83744 & & & \\
\hline lambda & -256.96777 & 24.87149 & & \\
\hline
\end{tabular}

Turning to the factors underlying the eating out expenditure, our main results are the following.

- Location matters a great deal. Households located in both metros and nonmetro urban locations are likely to spend larger amounts on eating out, relative to rural areas. Between the metros and non-metros, households in the former are likely to spend much larger amounts.

- Both SCs/STs and OBCs are likely to spend lower amounts relative to Others. 
Table 16

Heckman Selection Model - MLE Results

\begin{tabular}{|c|c|c|c|c|}
\hline \multirow{5}{*}{$\begin{array}{l}\text { Heckman selection model } \\
\text { (regression model with sample selection) }\end{array}$} & \multicolumn{2}{|c|}{ Number of obs } & \multicolumn{2}{|l|}{41349} \\
\hline & \multicolumn{2}{|c|}{ Censored obs } & \multicolumn{2}{|l|}{29697} \\
\hline & \multirow{2}{*}{\multicolumn{2}{|c|}{$\begin{array}{l}\text { Uncensored obs } \\
\text { Wald chi2(10) }\end{array}$}} & \multicolumn{2}{|l|}{11652} \\
\hline & & & 548.52 & \\
\hline & \multicolumn{2}{|c|}{ Prob $>$ chi2 } & \multicolumn{2}{|l|}{0.0000} \\
\hline Log pseudolikelihood $=-4.74 \mathrm{e}+08$ & Coef. & Robut Std. Err & $\mathrm{z}$ & $\mathrm{P}>|\mathrm{z}|$ \\
\hline \multicolumn{5}{|l|}{ Eating out - Rs. } \\
\hline Metro & 104.2238 & 11.2702 & 9.25 & 0 \\
\hline Urban & 47.15219 & 5.799586 & 8.13 & 0 \\
\hline SC/ST & -45.25382 & 5.102639 & -8.87 & 0 \\
\hline OBC & -37.58008 & 8.516833 & -4.41 & 0 \\
\hline Expenditure Poverty Ratio & 26.57366 & 2.653255 & 10.02 & 0 \\
\hline No. of adult males in paid work age group $18-24$ & 5.279526 & 5.651607 & 0.93 & 0.35 \\
\hline No. of adult males in paid work age group 25-45 & 19.95253 & 5.85688 & 3.41 & 0 \\
\hline No. of adult males in paid work age group $>45$ & 20.97598 & 13.91832 & 1.51 & 0.13 \\
\hline share of salary in total income & -0.2054892 & 0.1046213 & -1.96 & 0.05 \\
\hline share of business income in total income & 0.5358787 & 0.3416282 & 1.57 & 0.12 \\
\hline cons & 121.2509 & 14.76449 & 8.21 & 0 \\
\hline \multicolumn{5}{|l|}{ Recode Eating out (0/1) } \\
\hline Metro & 0.1501872 & 0.0390624 & 3.84 & 0 \\
\hline Urban & 0.2013181 & 0.0203902 & 9.87 & 0 \\
\hline Nuclear Family & 0.2849823 & 0.0407049 & 7 & 0 \\
\hline Joint family & 0.4013781 & 0.0424468 & 9.46 & 0 \\
\hline SC/ST & -0.0368894 & 0.0245217 & -1.5 & 0.13 \\
\hline OBC & 0.097246 & 0.0232568 & 4.18 & 0 \\
\hline Expenditure Poverty Ratio & 0.1194413 & 0.007103 & 16.82 & 0 \\
\hline No. of adult males in paid work age group 18-24 & 0.0971875 & 0.0240406 & 4.04 & 0 \\
\hline No. of adult males in paid work age group 25-45 & 0.0993962 & 0.0194385 & 5.11 & 0 \\
\hline No. of adult males in paid work age group $>45$ & 0.0253304 & 0.0297687 & 0.85 & 0.4 \\
\hline No. of adult females in paid work age group $18-24$ & 0.1721438 & 0.0446598 & 3.85 & 0 \\
\hline No. of adult females in paid work age group 25-45 & 0.1119627 & 0.0245254 & 4.57 & 0 \\
\hline No. of adult females in paid work age group $>45$ & -0.0177909 & 0.0401841 & -0.44 & 0.66 \\
\hline share of salary in total income & 0.1656913 & 0.0306916 & 5.4 & 0 \\
\hline share of business income in total income & 0.0014672 & 0.0011262 & 1.3 & 0.19 \\
\hline cons & -1.376383 & 0.0468827 & -29.36 & 0 \\
\hline /athrho & -0.2241698 & 0.0411004 & -5.45 & 0 \\
\hline /Insigma & 5.392404 & 0.0817619 & 65.95 & 0 \\
\hline rho & -0.2204888 & 0.0391023 & & \\
\hline sigma & 219.7311 & 17.96563 & & \\
\hline lambda & -48.44823 & 6.923901 & & \\
\hline
\end{tabular}

- The higher the number of adult males in paid employment in the age-group 25 to 45 , the greater is the amount spent. A similar result is obtained for the number of adults in paid employment in the older age group, $>45$ years, but the coefficient is only weakly significant. 
- The effect of higher per capita expenditure relative to the poverty line is large and significant, confirming that the more affluent are not just likely to eat out more often but also likely to spend larger amounts.

- Somewhat surprisingly, the higher the share of salary in household income, the lower is the amount spent. By contrast, the higher the share of business income, the larger is the amount spent.

In sum, most of the results are plausible. Specifically, location of households, their demographic and caste characteristics and, above all, their relative affluence influence both the decision to eat out, and, conditional on it, the amount spent.

\section{Concluding Observations}

The main findings are summarised from a broad policy perspective.

Attention was drawn to growing affluence, urbanisation and dietary changes that are occurring at a rapid pace in developing countries. Of particular significance in the Indian context is the expansion of the middle class, higher female participation, emergence of nuclear two-income families, a sharp age-divide in food preferences with younger age-groups more susceptible to new foods advertised in the media, and a rapid growth of super markets and fast food outlets.

There have been concomitant changes in dietary patterns. Consumption of animal products - especially fats - has increased but that of vegetable products only moderately. Among the latter, consumption of wheat, starchy roots, vegetable oils and sweets and sweeteners, and fruits has increased while that of rice, pulses and other cereals has declined. Also, the forms in which some of these products are consumed has also changed - chapatti, for example, is increasingly replaced by commercialised and westernised bread products.

Health implications of these dietary patterns are, however, not clear-cut. On the one hand, a more varied and nutritionally balanced diet and higher levels of food hygiene are associated with better health outcomes. On the other, although energy dense foods associated with fast food outlets are cheaper and convenient, these are also linked to a higher incidence of diet-related non-communicable diseases or NCDs (e.g. diabetes, coronary heart disease). Although India lags behind other developing countries in the epidemiological transition - decline in infectious disease mortality is increasingly compensated for by higher mortality from chronic degenerative NCDs - there is some evidence of this trasition taking place.

Viewed from this perspective, our analysis broadly confirms the important role of urbanisation, demographic changes, expansion of middle class and its growing affluence in eating out, or, more generally, consumption of snacks, beverages and precooked meals. To the extent that even more deprived sections are not immune to these evolving dietary patterns, and, given their limited access to medical care and dietary awareness, the health outcomes may well be a lot grimmer than often acknowledged. 
Annex

Fig 1: Distribution of Households Eating Out

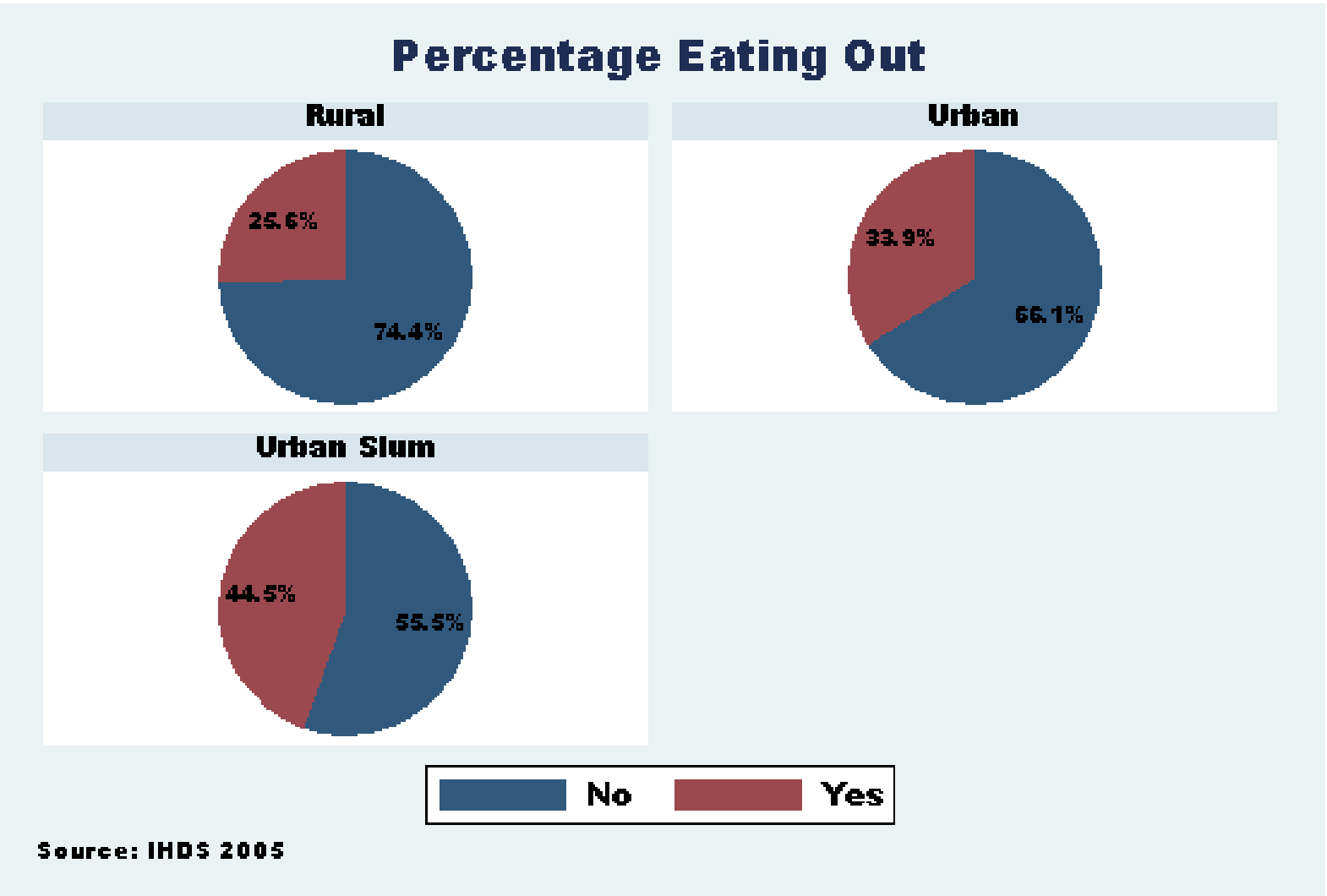


Fig 2: Distribution of Households Eating Out by MPCE (Rs)

(a) Rural

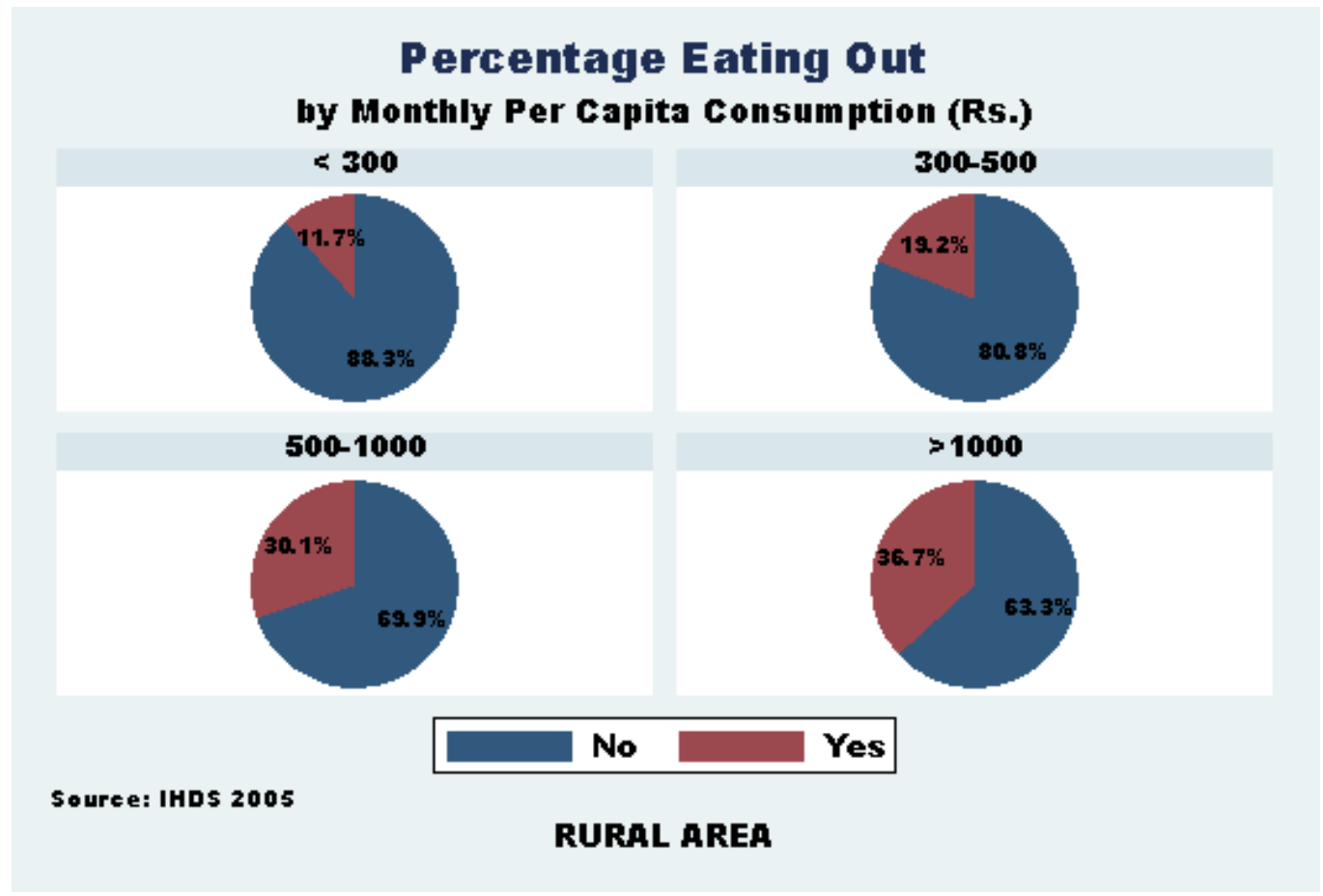

(b) Urban

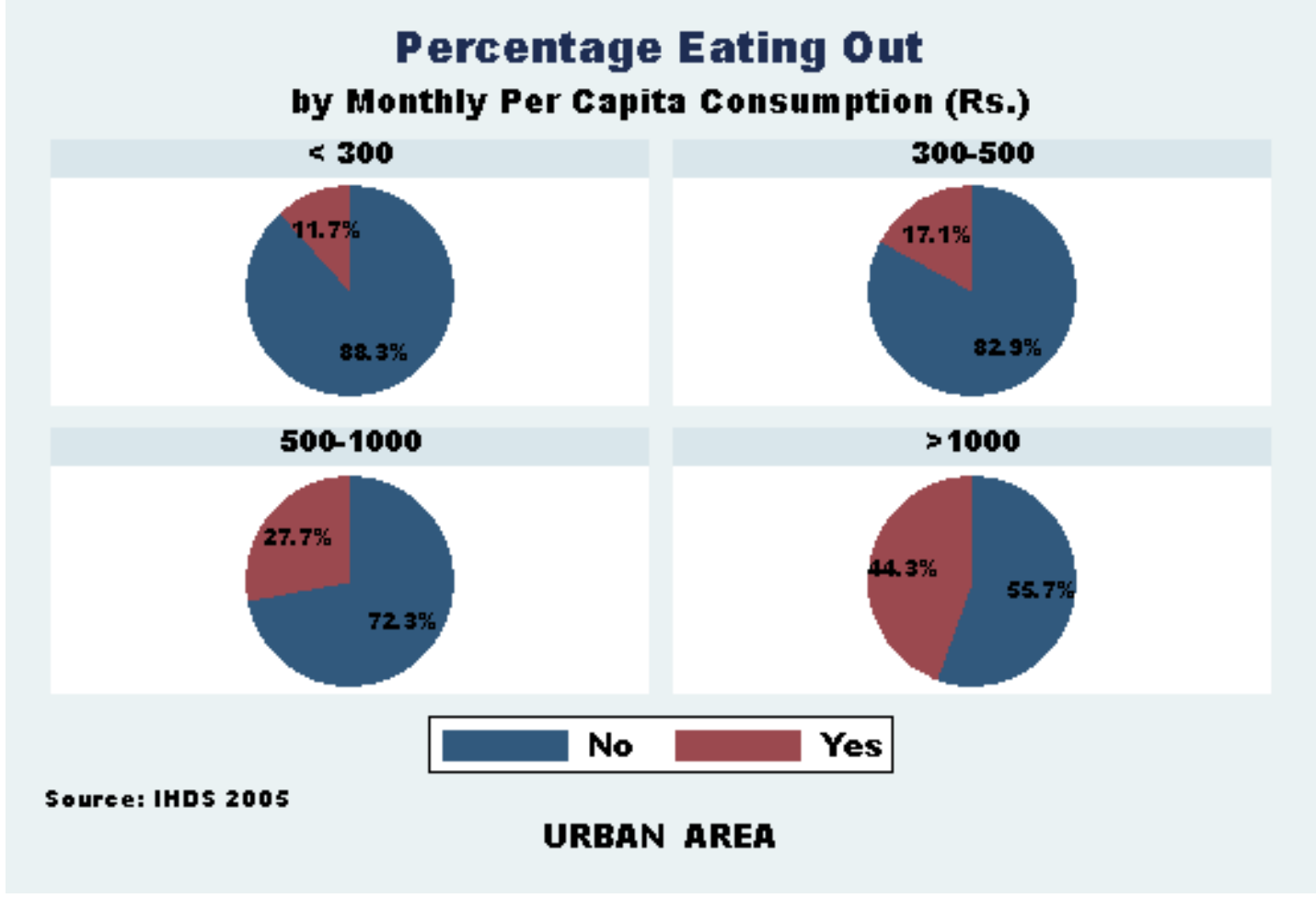


(c) Urban Slums

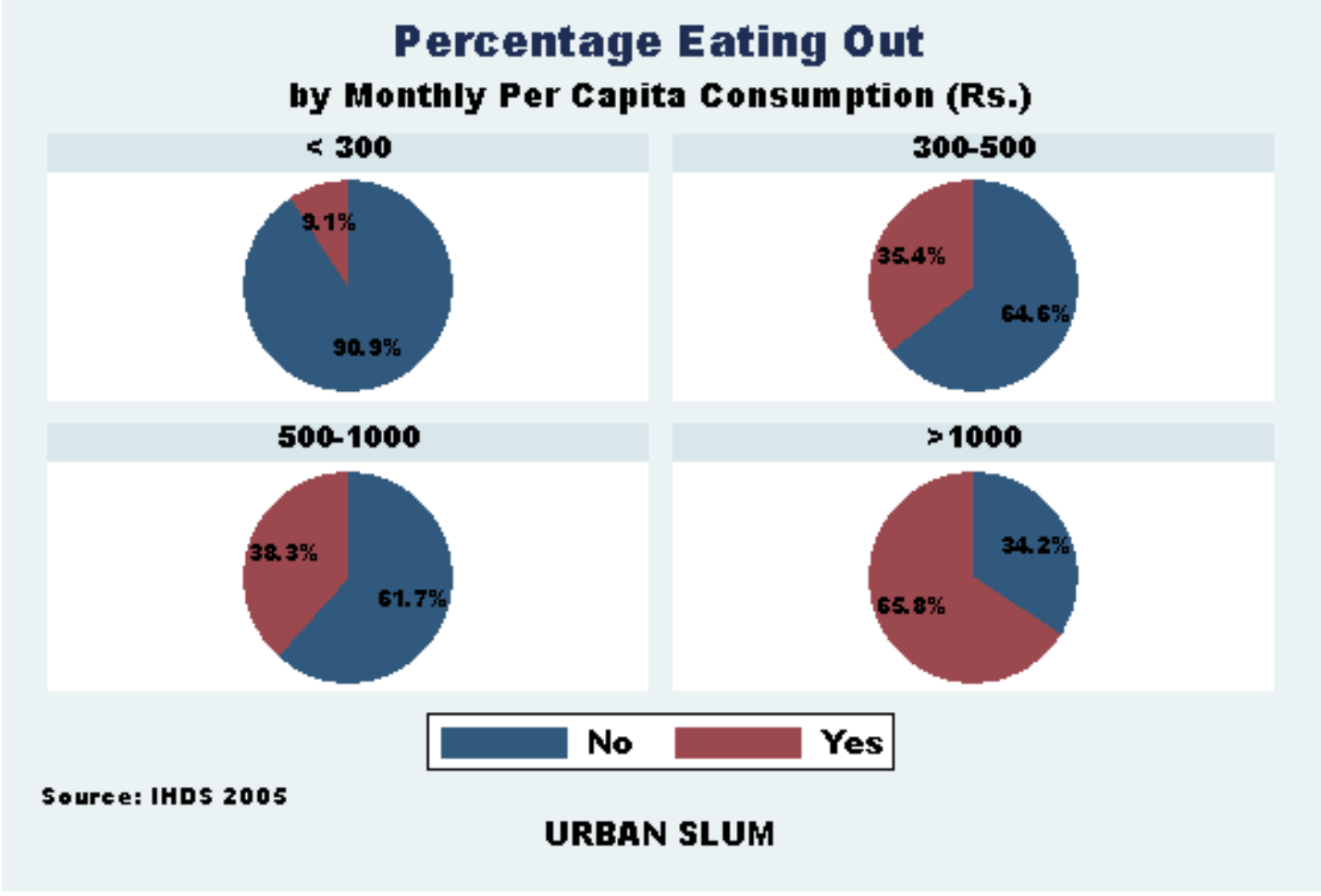

(d) Aggregate

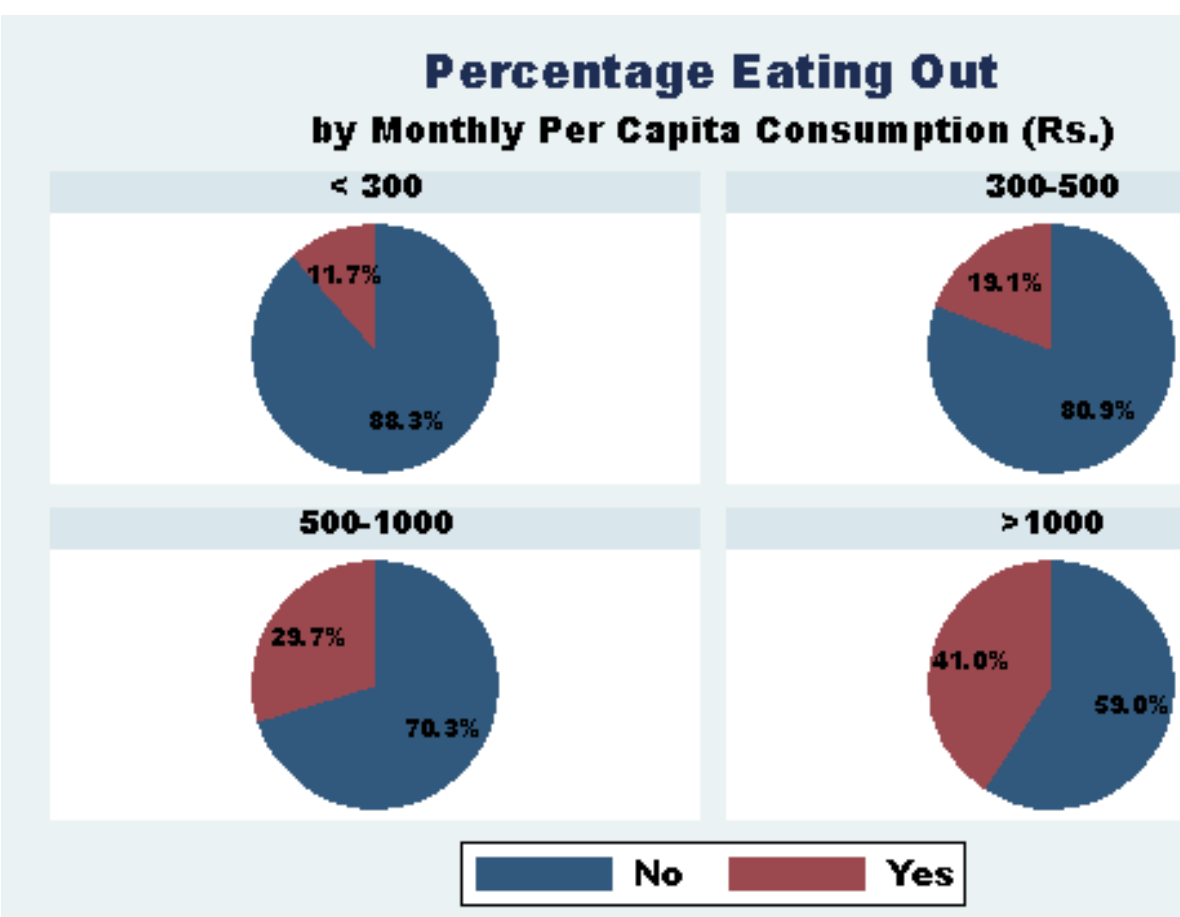

Source: IHDS 2005 
Fig. 3: Distribution of Households by Eating Out Expenditure by Family Type (Nuclear)

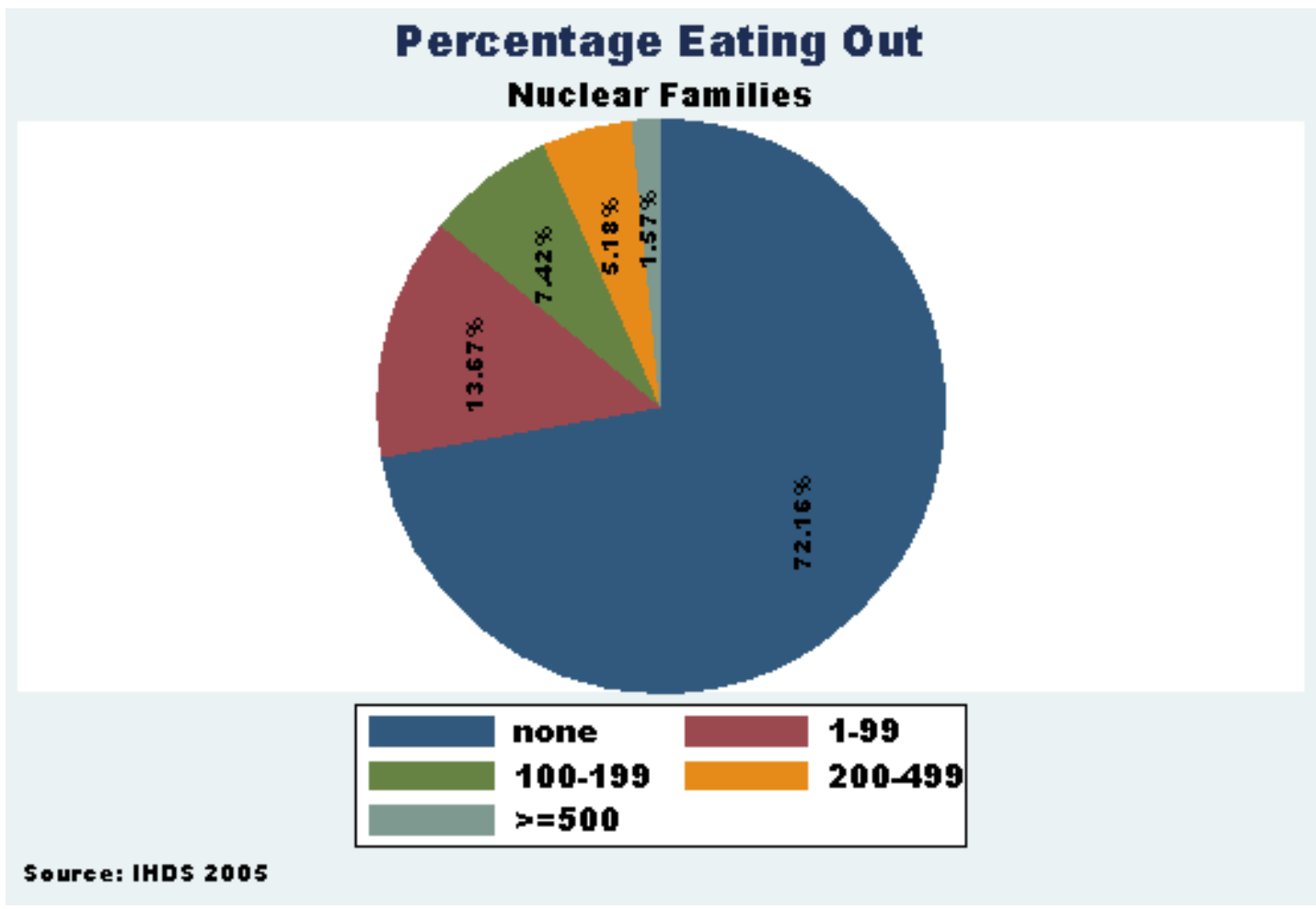

(Joint)

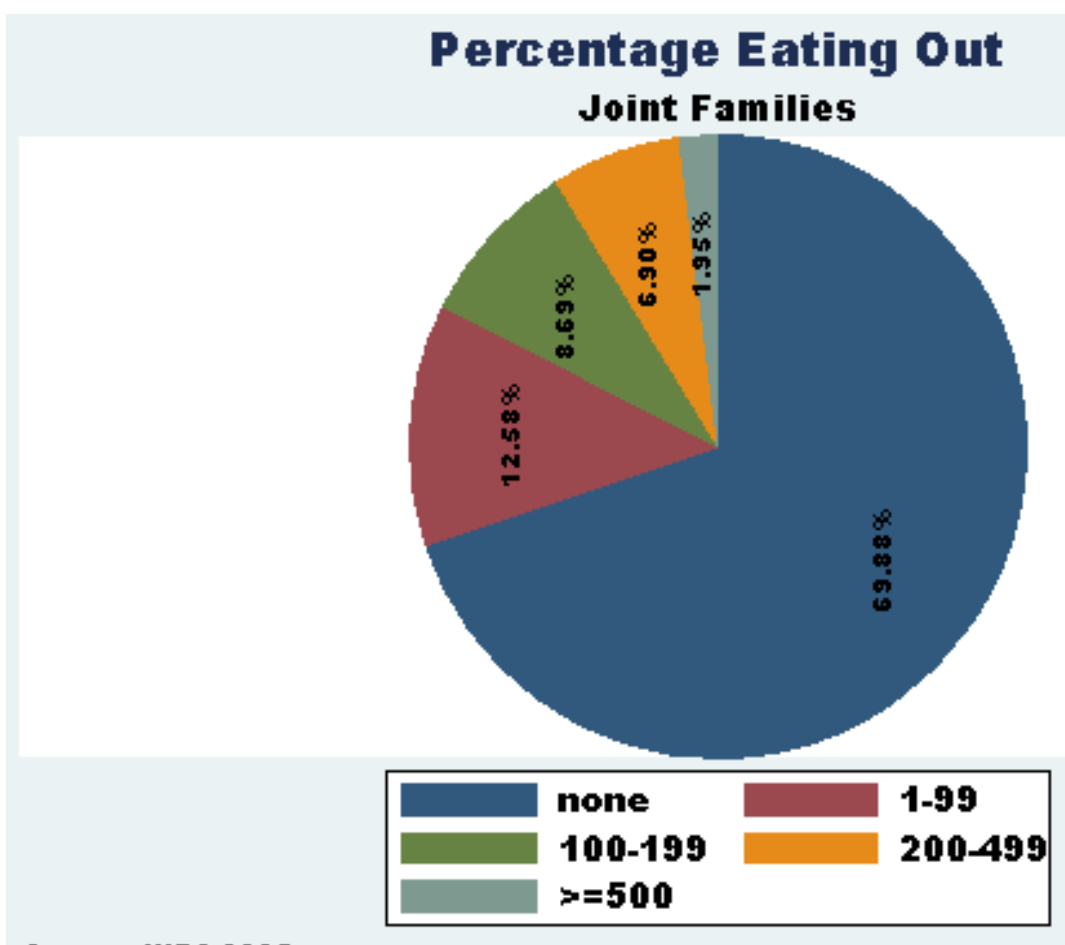

Source: IHDS 2005 
(Others)

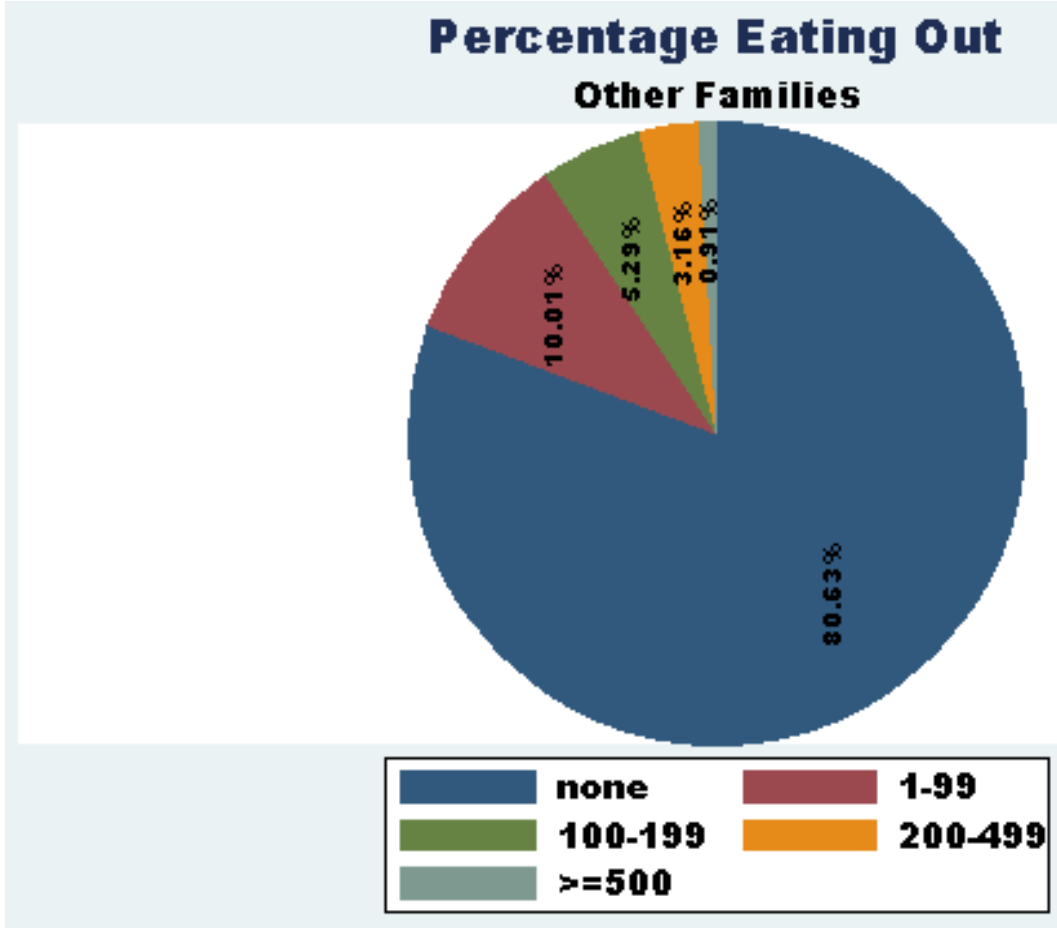

Source: IHDS 2005 


\section{References}

Adkins, L.C. and R.C. Hill (2008) Using Stata for Principles of Econometrics, Hoboken, NJ: John Wiley \& Sons.

Deaton, A. and J. Dreze (2009) "Food and Nutrition in India: Facts and Interpretations", Economic and Political Weekly, XLIV (7), 42-65.

Gaiha, R., G. Thapa, K. Imai and Vani S. Kulkarni (2008) "Has Anything Changed? Deprivation, Disparity and Discrimination in Rural India", Brown Journal of World Affairs, Spring/Summer.

Himanshu (2007) "Recent Trends in Poverty and Inequality: Some Preliminary Results", Economic and Political Weekly, XLII (6), 497-508..

Jha, R., R..Gaiha and A. Sharma (2009) "Calorie and Micronutrient and Poverty Nutrition Traps in Rural India”, World Development, 37 (5), 982-991.

Mahal, A., A. Karan and M. Engelgau (2009) The Economic Implications of NonCommunicable Diseases for India, draft.

Mahal, A., and A. Karan (2008) "Adequacy of Dietary Intakes and Poverty in India: Trends in the 1990s", Economics and Human Biology, 6 (1), 57-74.

Pingali, P. (2007) "Westernisation of Asian Diets and the Transformation of Food Systems: Implications for Research and Policy", Food Policy, 32 (3), 281-298.

Pingali, P. and Y. Khwaja (2004) "Globalisation of Indian Diets and the Transformation of Food Supply Systems”, ESA Working Paper No. 04-05, Rome: FAO.

Popkin, B., S. Horton, S. Kim, A. Mahal, and J. Shuigao (2001) “Trends in Diet, Nutritional Status, and Diet-Related Non-Communicable Diseases in China and India: The Economic Costs of the Nutrition Transition", Nutrition Reviews, 59 (12), 379-390.

Reddy, K. Srinath, B. Shah, C. Varghese, A. Ramadoss (2005) "Responding to the Threat of Chronic Diseases in India", The Lancet, October 5.

Shetty, P.S. (2002) "Nutrition Transition in India”, Public Health Nutrition, 5 (1A), 175-182.

Timmer, C.P. (2009) "Do Supermarkets Change the Food policy Agenda?", World Development, forthcoming.

Wooldridge, J.M. (2006) Introductory Econometrics, Mason, OH: Thomson: South Western. 